\title{
The Presence of the Past in Thucydides
}

\section{JoNAS GRETHLEIN}

\section{From meaning to presence}

Connor was not the first to tackle "narrative discourse" in Thucydides, nor have historians such as Kagan ceased to build their accounts of the Peloponnesian War on his work, but, by and large, in the last decades interest has shifted from Thucydides historicus to Thucydides narrator. ${ }^{1}$ Hornblower, Rood and others have demonstrated how Thucydides subtly creates historical meaning through narrative presentation. ${ }^{2}$ The recent interest in Thucydides as artful narrator has been inspired at least partly by Hayden White's Metahistory. In comparing the works of modern historians and philosophers of history with one another, White made a strong case for the role of emplotment in historiography. Despite the historians' self-fashioning as objective, their works heavily draw on the means of narrative and, as White provocatively proclaimed, cannot be sharply distinguished from fiction. The focus on the "content of the form" has proven particularly fruitful for the polished narratives of ancient historians. The new approach led to a re-assessment especially of Thucydides who had been hailed as the founding father of critical historiography.

Driven by the general attacks levelled against the linguistic turn, however, the theory of history has moved beyond Metahistory. Concepts such as presence, experience and materiality, given short shrift by scholars trained in deconstruction, are now being revived as a means of escaping the prison of language. ${ }^{3}$ Three examples may illustrate this shift in the theory of history: Ankersmit, formerly one of the best known advocates of tropology, has made a volte-face and now argues that histor-

1. Cf. Connor 1985; Kagan 2003. For an early study of Thucydides as artful narrator, see Cornford 1907.

2. Hornblower 1994b; Rood 1998.

3 See, e.g., Gumbrecht 2004 on presence; Jay 2005 on experience; Miller 2006 on materiality. 
ical experience precedes linguistic presentation of the past. ${ }^{4} \mathrm{~A}$ similar "New Romanticism" can be discovered in the works of Gumbrecht, who homes in on the presence of the past and foregrounds our sensual experience of it. ${ }^{5}$ Most recently, Runia has made a case for envisaging our relation to the past not so much in the "trope" of metaphor, as done by White and his disciples, as in the form of metonymy. ${ }^{6}$

Opposition to the linguistic turn has prompted the scholars just mentioned to contrast experience and presence with narrative and presentation. This, I have argued in a History \& Theory article, does not do justice to the capacity of narrative to convey experiences. ${ }^{7}$ Narrative is of course posterior to, and transforms, experience, just as experience cannot fully be represented in narrative; and yet narrative is nonetheless an important medium for experience. In particular its sequential character not only allows narrative to represent experience, but also gives the reception of narrative the form of an experience. We can, with some important qualifications, re-experience the past through narrative. While my approach focuses on the potential of narrative, it is very different from the interest in narrative emplotment triggered by White's Metahistory. I am not interested in the construction of historical meaning, but in narrative's capacity to make the past present. This ultimately re-introduces the notion of reference that has been banished by poststructuralist theoreticians. ${ }^{8}$

Thucydides is a strong case in point for the "re-presentation" of the past in narrative. Plutarch, for example, notes: "Thucydides is always striving for this vividness in his writing, since it is his desire to make the reader a spectator, as it were, and to instil in readers the emotions of amazement and consternation felt by witnesses". (De glor. Ath. 347a). Recent scholarship has focused on Thucydides' deployment of narrative means for his interpretation of the past, but the experiential character of his account has not gone unnoticed. ${ }^{9}$ Thucydides serves for example as a cornerstone of Dunn's argument that the end of the $5^{\text {th }}$ century saw a "present shock"; that, in other words, political turmoil

4 Ankersmit 2005.

5 Gumbrecht 1997.

6 Runia 2006

7 Grethlein 2010b

8 In Grethlein 2010 b, 327-329, I suggest the concept of a secondary reference.

9 Besides the works discussed above, see also Kitto 1966, 298-9; Connor 1985; Greenwood 2006, 19-41; Grethlein 2009, 164-171; 2010a, 248-252. On enargeia in Greek historiography in general, cf. Walker 1993. and cultural change brought about an intense focus on the present. ${ }^{10}$ In his interpretation of the Corcyrean conflict, Morrison distinguishes three points that "create a particular type of experience for the reader": 11 multiple perspective, authorial reticence and episodic structure. In the terms of narratology, Thucydides' orchestration of focalisation, voice and time lets the reader re-experience the past as if it were present: The employment of various viewpoints makes the narrative vivid. Only rarely does the authorial voice intervene and remind the reader of its mediating function. Most important, perhaps, is the temporal organisation of the narrative, which reports the events of the various theatres of war season by season. ${ }^{12}$ Thucydides does not capitalize on the advantage of hindsight and tends to avoid prolepses; thus the reader is by and large limited to the perspective of the historical agents. ${ }^{13}$ Of course, the backwards gaze of historiography separates the historical agents from Thucydides and his readers. What is still future for the former is already past for the latter. That being said, Thucydides' account illustrates how far a historian can go in abandoning the advantage of hindsight and making the past present through narrative.

In this paper, I will explore further devices with which Thucydides restores presentness to the past. More specifically, I will shift the focus from the shiny pearls of Thucydides narrative, which, only too understandably, dominate in studies of his vividness, to less prominent passages. Instead of discussing obviously mimetic passages such as the final battle in the harbour of Syracuse, I will tackle two minor episodes, Phormion's two naval victories in 2.83-92 (part 2) and the capture of Mytilene in 3.25-34 (part 3) in order to explore the experiential quality in less noteworthy parts of the narrative. My findings will be qualified by a look at un-experiential features and traces of teleological design (part 4). A brief comparison with Plutarch will finally illustrate that the experiential quality of Thucydides' narrative is nuanced differently from the ancient concept of enargeia (part 5).

10 Dunn 2007, 111-150

11 Morrison 1999, 94.

12. On the temporal organization of Thucydides' account, see Dewald 2005.

13 See, however, the qualification in section 4. 


\section{Phormion's double victory $(2.83-92)$}

My first example is Thucydides' report of the first two major sea battles between the Athenians and Spartans. In the first encounter, which takes place in the gulf of Acarnia, Phormion and 20 Athenian ships defeat a Peloponnesian fleet of 47 ships under Cnemon, transporting troops to Acarnania (2.83-84). Thucydides begins his account with Phormion's plan: to wait for the off-shore wind, which will confuse the enemy; then to attack $(2.84 .1-2)$. The battle proceeds in accordance with Phormion's plan: the wind throws the Peloponnesian ships into disarray, making them easy prey for the Athenians (2.84.3-4).

After the battle, Cnemon and advisors arriving from Sparta collect further ships from their allies, bringing the fleet to 77 ships, whereas 20 ships sent from Athens linger in Crete and come too late for the second battle, off Naupactus (2.85-6). Thucydides first gives us the speeches addressed to the soldiers before this encounter (2.87-9) and continues by reporting the Spartan stratagem, namely to sail toward Naupactus and to force Phormion to follow them into the bay $(2.90 .1-2)$. And indeed, this strategy permits the Spartans to battle the Athenians in the narrows. Only eleven Athenian ships escape to Naupactus, the rest are captured by the Spartans (2.90.3-91.2). Then the tables are turned most unexpectedly. The last of the Athenian ships headed to Naupactus sails around a merchant vessel and attacks and sinks the first of the pursuing ships. The ensuing confusion in the Spartan fleet prompts the Athenians to sail quickly back and rout their enemies. Thus, 20 Athenian ships defeat a Spartan fleet of 77 (2.91.3-92). In the following, I would like to discuss several devices which contribute to the experiential quality of this narrative: graphic description, tense, internal focalisation, speeches and composition.

\section{Graphic description and tense}

Central to ancient as well as modern discussions of Thucydides' enargeia are passages with a strong graphic quality. ${ }^{14}$ In the chapters on Phormion's two sea battles, the description of the first battle illustrates this device of making the past present (2.84.3):

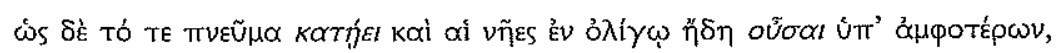

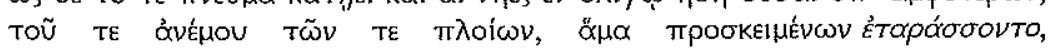

14 See Plut. De glor. Ath. 347a quoted above; in modern scholarship, see Connor 1985; Walker 1993, 355-356.

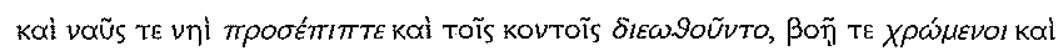

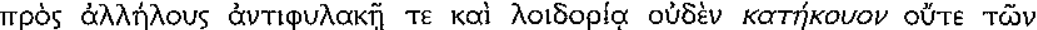

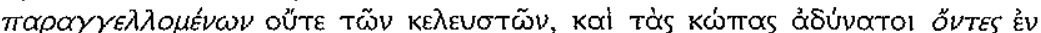

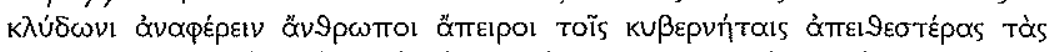

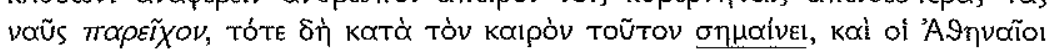

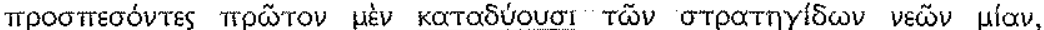

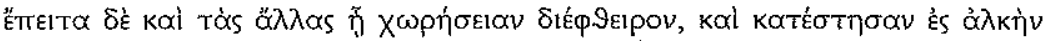

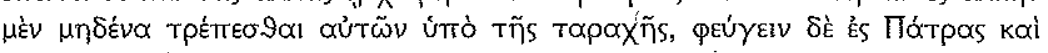

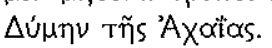

And when the wind blew down and the ships, already in a small space, were disordered by both together, the wind and the boats; and ship collided with ship, and they were pushed apart with poles; and the crews, shouting and fending one another off with abuse, listened neither to orders nor their officers and, in their inexperience unable to lift their oars in the ocean swell, made the ships less responsive to the helmsmen; it was then, at that moment, that Phormion gave the signal; and falling upon the enemy, the Athenians first sank one of the generals' ships and then destroyed the others wherever they went, and brought it about that none turned to resist in the confusion, but they fled to Patrai and Dyme in Achaia. ${ }^{15}$

While the battle itself is briefly summarized, the confusion created among the Peloponnesian ships by the wind is described in detail. Their attempts to push the ships apart with poles, the inability of the rowers to move their oars in the waves, and the noise that makes it impossible to pass on orders lend the passage much vividness. The disorder of the ships is stylistically mimicked through the long sentence with its menandering participles and parentheses.

The tenses of the verbs may contribute to the enargeia of the passage: the confusion of the Peloponnesians is described in the imperfect tense and present participles (italics). The choice of this tense can be explained in various ways: it could be used to indicate the circumstances of the action, the attack, or it could express the durative and iterative aspect of the manoeuvres. Another aspect may also come into play. In a paper on tenses in Thucydides, Bakker argues that tenses may have significance in addition to temporal reference, namely to signal the relative distance of the events narrated. ${ }^{16}$ In this scheme, aorist forms foreground mediation by a narrator distant from the events narrated, whereas imperfect forms place an account in the past, in the time of the events. If we follow this argument, the dominance of the imperfect tense in the pas-

15 This as well as the following translations of Thucydides is based on Lattimore 1998.

16 Bakker 1997. 
sage quoted above would also serve to present the events "as if they are seen on the spot". ${ }^{17}$

While the confusion of the ships is reported in the imperfect tense, Phormion's signal and the Athenians' attack are narrated in the present tense (underlined). This closely conforms to Rutger Allan's argument that Thucydides uses the historical present in order to underline turning points in the action through "epistemic immediacy". ${ }^{18}$ In our passage, the imperfect brings the reader close to the scene and the historical present endows the turning point with additional immediacy and emphasis. Together, the two tenses reinforce the graphic quality of the description and let the reader follow the battle as if it was unfolding right before her eyes.

\section{Internal focalisation}

Another important mimetic device in Thucydides' narrative is internal focalisation. Focalisation lets the reader envisage the past as present by reporting the events from the perspective of the agents..$^{19}$ Despite its etymology, focalisation is not limited to seeing, but embraces all senses as well as intellectual activities and emotional response. ${ }^{20}$ Its prominence in Thucydides' narrative style is nicely illustrated by his account of the manoeuvres leading up to the first sea battle $(2.83 .2-3)$ :

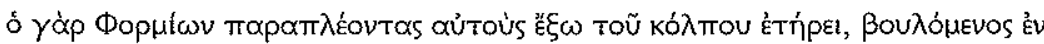

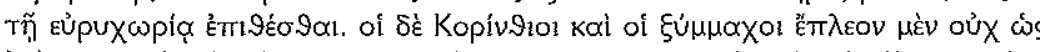

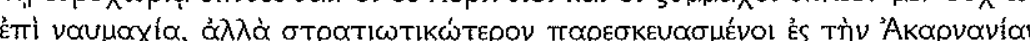

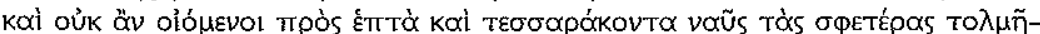

17 Bakker 1997a, 18.

18 Allan 2011a.

19 The prominence of perception (in narratological terminology focalisation) in Thucydides has been tackled from different perspectives: Montgomery 1965, 45-95, de Romilly 1956b and Schneider 1974 explore the function of reasoning and intentions; Hunter 1973 argues that Thucydides derives the characters' purposes from the facts in order to question his objectivity; Westlake 1989a, $201-223$, on the other hand, tries to show that "personal motives, aims and feelings" are often based on "information obtained directly from the individual to whom motives or feelings are ascribed or from one or more close associates believed to be trustworthy" (201); Lang 1995 surveys the expression of motivation by participles; Rood 1998, 61-82 gives a narratological analysis showing that "Thucydides' focus on perceptions helps to explain events" (80); Stah 2003 emphasizes the disappointment of expectations. See also Tamiolaki (this volume) on motives in Thucydides.

20 Cf. Nelles 1997, ch. 3 on focalisation and senses and Rimmon-Kenan 1983

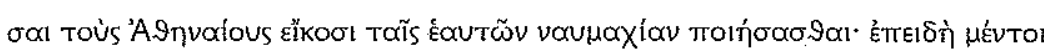

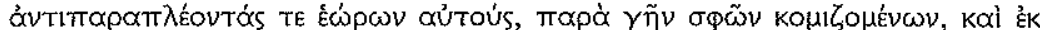

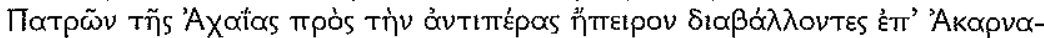

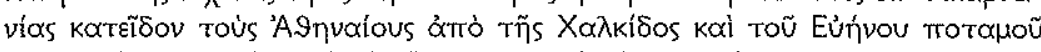

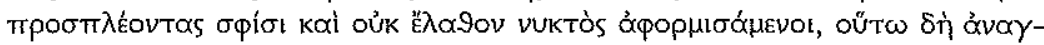

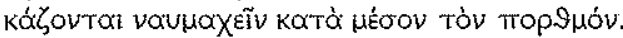

Phormion watched for them to sail along the coast and out of the gulf, since he wanted to attack on the open sea. The Corinthians and their allies were not sailing toward Acarnania prepared for a sea battle but were equipped more as transports and did not believe that the Athenians, with their twenty ships, would dare to fight a sea battle against fortyseven; yet when they observed them [i.e. the Athenians] sailing along the opposite coast while they were close to land themselves and, as they were crossing from Patrai in Achaia toward Acarnania on the opposite mainland, saw the Athenians sailing toward them from Chalkis and the Evenus river, and they [i.e. the Corinthians] did not elude them [i.e. the Athenians] by setting sail at night, they were now indeed forced to fight a sea battle in the middle of the gulf.

Thucydides reports not so much the movements themselves, but rather concentrates on the characters' perceptions, expectations and motives:

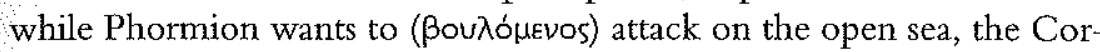

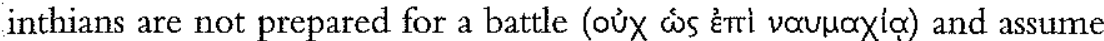
(oủ... oiómevol) that the Athenians will not dare to approach their superior force. The following movements are focalised by the Corinthians: they see $(\varepsilon \dot{\omega} \rho \omega v)$ the Athenians sail along the opposite coast and ob-

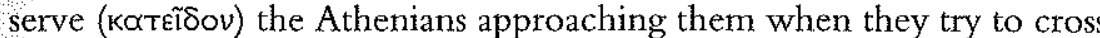
the sea. "And they [i.e. the Corinthians] did not elude them [i.e. the Athenians] by setting sail at night" returns the focalisation to the Athenians, subtly interweaving it with the plan of the Corinthians: while

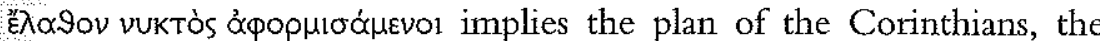
negation expresses the Athenians' noting it.

There are several cases in which the two stances of focalisation are superimposed. In 2.89 .4 and 6 , for example, Phormion argues that the Peloponnesians are full of fear, and later, in 2.90 .2 , the Peloponnesians they take into account what the Athenians will think:

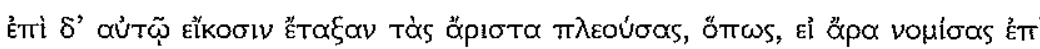

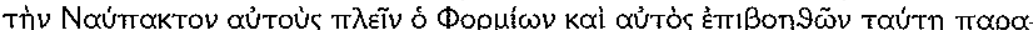

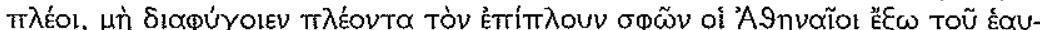

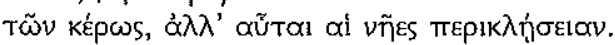

On this wing they stationed their twenty best sailers, so that now, if Phormio thought they were sailing against Naupactus and sailed along the coast in that direction himself to defend it, the Athenians would not escape their 
attack beyond the reach of their wing, but these ships would close in on them.

Here, one character focalises the focalisation of another. The doubling forcefully pulls the reader into the world of the action as it is experienced by the historical agents.

In the introductory remarks, I pointed out that the chronological progression of the story and the avoidance of anachrony are crucial to the experiential quality of Thucydides' historiography. The account of the Naupactus battle furnishes an analepsis that interrupts the chronological order but nonetheless serves to re-create the presentness of the past. Thucydides announces that. Phormion wanted to encourage his men and adds (2.88.2):

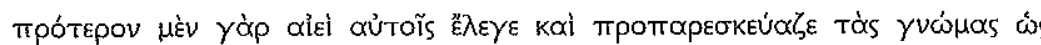

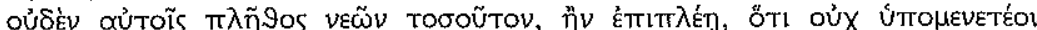

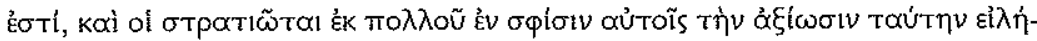

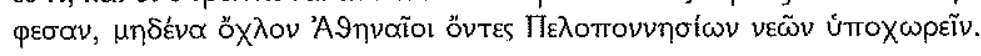

In the past he always told them and conditioned them to think, that for them no naval force was so large that they could not withstand its attacks, and the crews had long since accepted this assessment among themselves, that as Athenians they did not give way before any horde of Peloponnesian ships.

Of course, this flashback does not follow the course of events, but it evokes the horizon of the soldiers who heard Phormion's encouraging words with his earlier comments in mind. The anachrony, which at first sight seems to interrupt the mimesis, is internally focalised and helps to present the action from the perspective of the agents. By reporting what took place indirectly and employing the focalisation of the characters, Thucydides gives his readers the feeling of witnessing the events as they unfold.

Speeches

In speeches, Thucydides not only adopts the perspective of the protagonists but also lets them speak in their own words. ${ }^{21}$ In an article on "frontières du récit", Genette reconsiders Plato's juxtaposition of direct speech (mimesis) with narrative (diegesis): "Platon opposait mimesis à die-

21 Scholarship on speeches in Thucydides has focused on the issue of their authenticity, e.g. Hornblower 1987, 45-72, and on their relation with the narrative, see besides de Romilly 1956b and Hunter 1973 also Morrison 2006a. See also the articles in Stadter 1973. gesis comme une imitation parfaite à une imitation imparfaite; mais l'imitation parfaite n'est plus une imitation, c'est la chose même". ${ }^{22}$ The direct presentation of utterances seems to give unmediated access to the past; in temporal terms, it makes narrated and narrative time converge. Speeches are thereby highly conducive to making narrative experiential. In the passage under consideration here, the speeches of the Spartan generals and of Phormion reveal how they assessed their present situation and what they conjectured about the future in the light of what had just happened: the Spartan generals attempt to dispel their men's fears by explaining away their previous defeat and highlighting their superiority. They adduce deficient preparation, bad luck and inexperience as the reasons for the defeat and invoke the courage and superior size of their fleet as factors that render them superior to the Athenians (2.87).

As commentators have not failed to notice, Phormion's address to his men closely corresponds to the speech of the Spartan generals. ${ }^{23}$ He tries to free the Athenians from their fear of the mighty Spartan fleet, which, he points out, only shows the fear of the Spartans, who refuse to meet them on equal terms. The Spartans are by no means more courageous than the Athenians, who moreover can rely on their superior naval experience. The very fact that the Athenians dare to confront them with a much smaller force will increase their fear. Phormion then lays out his strategy: he intends to avoid fighting in the narrows; he prefers the open sea, where the Athenians can cash in on their technical superiority. After emphasizing the importance of order and silence, Phormion finally calls attention to what is at stake: victorious, they can discourage further Spartan expeditions at sea, but, in the event of defeat, they will jeopardize Athens' naval supremacy (2.89). While not directly advancing the plot, these speeches evoke the temporal horizon of the historical agents and make the readers perceive the past through their lens; more specifically, they align the readers with the soldiers listening to the generals.

Speeches and focalisation also buttress the mimetic appeal of the narrative in other respects: Thucydides uses them to convey much information, not by his narratorial voice but at the level of the action. Speeches thus contribute to Thucydides' authorial reticence. His description of the first battle, for example, is very short; the narrative can focus on the confusion of the Peloponnesians, because the Athenian

22. Genette 1966,156

23 Luschnat 1942, 26-7; de Romilly 1956b, 140-143. 
strategy has already been laid out in the reflections attributed to Phormion. ${ }^{24}$ The account of the second battle is more complex, but again important pieces of information are introduced at the level of the action. This comes to the fore in Gomme's comments on the tactical considerations found in Phormion's speech: "All this explanation of the advantages of open waters to the Athenians seems out of place in an address immediately before a battle to well-trained sailors; it is Thucydides rather, reminding the reader". ${ }^{25}$ The Spartans' speech, on the other hand, is limited to an evaluation of the first battle and encouragement for the imminent encounter, but the reader also learns their strategy, which Thucydides, with great narrative economy, reports directly before the battle $(2.90 .1-2)$. The focalisation lends presentness to the account, which at the same time is given dramatic force by the late revelation of the strategy that will determine the first part of the battle. By having the historical agents focalise and voice important pieces of information, Thucydides reduces the visibility of his narratorial mediation and gives the reader the impression that she is following the events as experienced by the historical agents.

Speeches embed in the action not only factual information but also interpretive elements. Noting the close correspondence of the speeches of the Spartans and Phormion, de Romilly states: "Phormion a donc ruiné, dans son ensemble, l'argumentation péloponnésienne". ${ }^{26}$ Phormion's speech reveals that the points on which the Peloponnesians build their confidence, their numerical superiority and their courage, are irrelevant: the fact that the Peloponnesians dare to confront the Athenians only with such a great fleet indicates their fear. In addition, courage is linked to experience, with which the Athenians easily surpass the Spartans at sea. ${ }^{27}$ Comparison of the two speeches with one another and with the following narrative sheds light on the action. The Athenians' swift turn from flight to attack illustrates the courage and experience that Phormion foregrounds in his pre-battle address. ${ }^{28}$ Seen from this perspective, the speeches allow Thucydides to evaluate the action

24 Cf. Luschnat 1942, 26; de Romilly 1956b, 145.

25 Gomme, HCT II, ad 2.89.9.

26 De Romilly $1956 \mathrm{~b}, 141$.

27 See also Hornblower 1991, ad 2.87.4: "In fact, as we are surely meant to recall, Pericles at 40.3 had claimed for Athens precisely the combination of thought and action which the Peloponnesian commanders here insinuate that she lacks".

28 De Romilly 1956b, 143-4; Hunter 1973, 53-55, who uses Phormion as evidence for her thesis that Thucydides tends to derive purposes from facts. without having to insert his narratorial voice - the evaluation is presented diegetically.

Another example for this is Phormion's comment in 2.89.10:

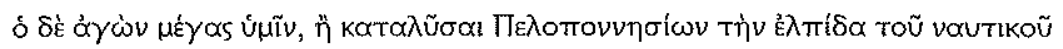

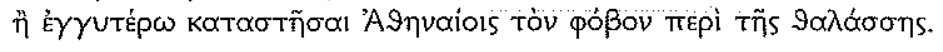

We are in a great contest, either to end the Peloponnesians' hopes for their navy or to bring closer to the Athenians their fear for the sea.

Thucydides refrains from narratorial intrusion, but lets Phormion make a remark about the importance of the battle. This interpretation adds an interesting facet to our understanding of speeches. It is widely agreed that Thucydides uses speeches to integrate general reflections into his narrative. Just think of the Plataean and Mytilenean debates: besides discussing specific situations, these speeches shed light on the conflict between justice and expediency in interstate relationships. Luschnat and de Romilly have shown that also in the Naupactus narrative the speeches extend the significance of the scene beyond the specific events involved, in the words of the latter: "Elles partent de l'immédiat pour s'élever, dans le domaine des idées, au niveau des grands discours politiques". ${ }^{29}$ At the same time, while transcending their contexts, these and other speeches contribute to the experiential character of the narrative, as we have just seen: the form of oratio recta collapses the difference between narrated and narrative time. Speeches also serve to integrate factual information, evaluation and deeper reflection into the level of the action, permitting Thucydides to keep a low profile as narrator. His authorial reticence, foregrounding the action, not only makes the narrative dramatic but also slyly lends authority to it, as the judgment seems to emerge from the events themselves.

\section{Composition}

A last point that enhances the mimetic dimension of Thucydides' account is the selection of narrative elements and their composition. While de Romilly and Hunter have explored the close correspondence between Phormion's plans and the course of events, Stahl has rightly drawn attention to the role of the unexpected in the second battle. ${ }^{30}$ The quickness and 9ópoos with which eleven Athenian ships rout a

29 De Romilly 1956b, 150; cf. Luschnat 1942, 31

30 De Romilly 1956b, 143-4; Hunter 1973, 53-55; Stahl 2003, 87-91. 
fleet of 77 may illustrate, as de Romilly and Hunter suggest, ${ }^{31}$ the experience and courage of which Phormion boasts in his speech, but it is only the fortuitous appearance of a merchant vessel that allows the Athe-

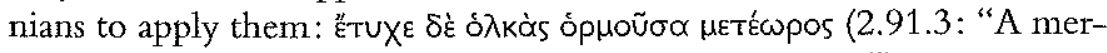
chant ship happened to be anchored in the open water").

The role of the unexpected is emphasized by the composition of the battle narrative, notably by the parallels to the first battle. ${ }^{32}$ As in the first battle, where Thucydides begins by focalising the reasoning of Phormion, he now informs us of the strategy of the Spartans: in both scenes, the subsequent narrative confirms his reasoning. A detail underscores the parallel: the signal that launches the Spartan attack echoes the signal for which the Athenians waited in the first battle (2.90.4 2.84.3). The parallel presentation leads the reader to expect that everything will again go according to plan: just as Phormion's plan had enabled the Athenians to overcome the Spartans in the first battle, analogously this time, the Spartans will emerge victorious. The narrative thereby re-creates for the reader the surprise that overtakes the Spartans and leads to the rever-

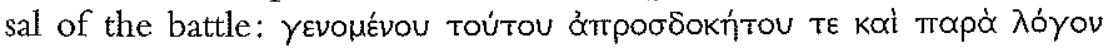
(2.91.4: "as a consequence of this unexpected and unlikely event"). Thus, Thucydides not only refrains from foreshadowing the subsequent course of the action but also arranges his narrative so that it conveys some of the experience of the historical agents.

To sum up: The account of Phormion's double victory illustrates several means by which Thucydides makes the past present. Graphic passages, tense, internal focalisation, speeches and narrative composition all contribute to the mimetic power of Thucydides' narrative. Of course, Thucydides writes in hindsight, and readers with some knowledge of the Peloponnesian War will remember the outcome of the sea battles. Nonetheless, the narrative compels the reader to witness the events as if they were just unfolding. History is always written in retrospect, but Thucydides enlists numerous narrative techniques to restore presentness to the past.

31 De Romilly 1956b, 147 on quickness; Hunter 1973, 54 on 9ópбos.

32 A comparison of the two battles is already suggested at the level of the action

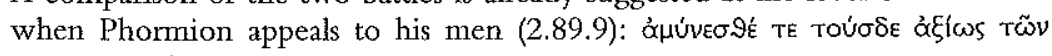

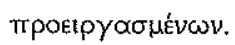

3. The Capitulation of Mytilene (3.25-35)

The second episode I would like to discuss in order to highlight the experiential quality of the History of the Peloponnesian War is the account of the capitulation of Mytilene. When the Athenians notice that Mytilene is trying to free Lesbos from their rule and to break free from the AtticDelic League, they start besieging the city. A Spartan messenger, Salaithus, promises the help of 40 Peloponnesian ships as well as a Spartan invasion of Attica and thereby encourages the Mytileneans to continue to endure the siege (3.25). ${ }^{33}$ However, while a Spartan army ravages Attica, the Mytileneans wait in vain for reinforcements from Sparta and finally capitulate $(3.26-8)$. In the meanwhile, the 40 Peloponnesian ships, under the command of Alcidas, arrive at Icarus and Myconus (3.29). In a brief direct speech, an Eleian named Teutiaplus suggests that the Spartans sail as fast as possible to Mytilene and take the Athenian corps by surprise (3.30). Alcidas rejects this proposal, as well as one made by some Ionians and Lesbians, reported in indirect speech, to sail to Ionia and to compel its cities to defect from the Athenians. Instead, Alcidas hurries back to the Peloponnese, pursued by the Athenian general Paches and his fleet $(3.31-33.1)$. When Paches fails to catch Alcidas, he captures the Colophonian city Notion, afflicted by stasis. He expels the Arcadian and Persian forces that had supported the dominant party and restores the exiles (3.33.2-34). On arrival in Mytilene, Paches arrests the Spartan Salaithus and sends him together with the leaders of the conspiracy to Athens (3.35). The episode of the capitulation of Mytilene precedes one of the most read passages in Thucydides, the Mytilenean Debate, and illustrates devices of making the past present seen in the account of Phormion's sea battles, as well as some new ones. In my discussion, I will briefly touch upon internal focalisation and composition together with narrative time and then explore narratorial manipulation of time, "sideshadowing" and indirect evaluation.

\section{Internal focalisation}

Since the episode of Phormion's naval successes has already provided us with ample material to illustrate focalisation as a mimetic device, I will limit myself to one example here. In 3.33, Thucydides notes that Alcidas quickly fled from Ephesus and adds (3.31):

33 On the narrative subtlety of this passage, see Rood 2006, 225-6. 


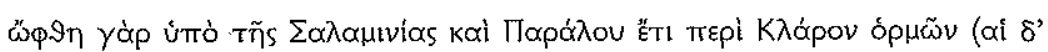

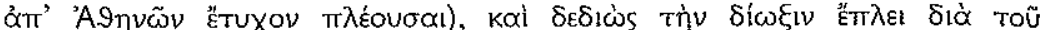

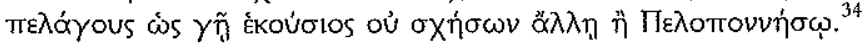

For he had been spotted by the Salaminia and Paralus while he was still anchored off Clarus; they happened to be sailing from Athens. Fearing pursuit, Alcidas sailed across the open sea with no intention of putting in anywhere but the Peloponnesus.

Here we have another example of a double focalisation: Alcidas notes that he has been seen by the Athenians. In the next paragraph, Thucydides turns to the Athenian side: Paches receives many warnings that the Peloponnesian fleet might attack the Ionian cities. One warning is singled out (3.33.2):

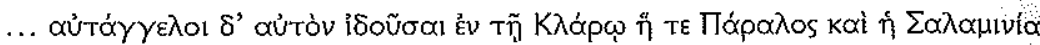
हैథp $\propto \sigma \alpha \nu$.

... and the Paralus and the Salaminia on their own evidence reported seeing Alcidas at Clarus.

It is striking that Thucydides, well known for his narrative economy, mentions the same fact twice within a single chapter, first through the eyes of the Peloponnesians, who quickly sail away when they notice they have been seen by the Athenians, then adopting the perspective of Paches, for whom the sighting of Alcidas in Clarus indicates the danger of an attack against unfortified Ionia. The repetition illustrates the prominence that Thucydides assigns to the perception of historical agents. Rather than concentrate on bald historical facts, Thucydides describes them as experienced by historical agents to make the reader view the past from their perspective, as if it were still present.

\section{Composition and narrative time}

In my interpretation of the battle at Naupactus, I argued that the repetition of the pattern of the first battle serves to re-create for the readers the surprise that caught the Peloponnesians and led to their defeat; the capitulation of Mytilene is narrated to similar effect. In chapter 25, Thucydides reports how Salaithus sneaks into Mytilene and discourages the citizens from capitulating. He announces that Sparta is about to invade Attica and will send 40 ships. In the following chapter, Thucydides turns away from the events in Mytilene to the invasion of Attica, which, he

34 On $\gamma$ óp as marking the focalisation of a character in Thucydides, see Horn blower 1994b, 134. points out, "was the most severe for the Athenians, after the second

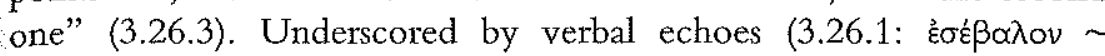
3.25.1: $\dot{\varepsilon} \sigma \beta \circ \lambda \eta$ ), this statement raises the expectation that the Spartans are keeping their promises and that Mytilene will continue its resistance. The first sentence of chapter 27 thus comes rather as a surprise (3.27.1):

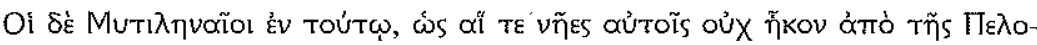

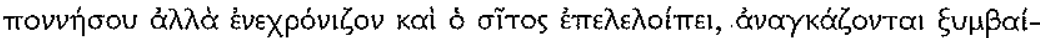

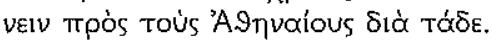

Meanwhile, the Mytileneans, since the ships did not arrive from the Peloponnesus but wasted time, and their food had run out as well, were forced to come to terms with the Athenians in the following way.

Only after Thucydides has narrated at length how and on what terms the Mytileneans capitulate, he reports what happened to the 40 Peloponnesian ships (3.29.1):

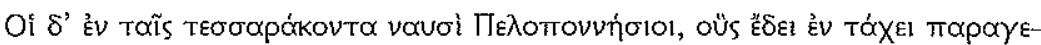

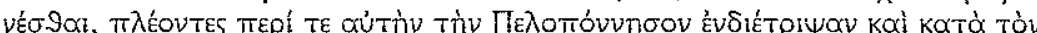

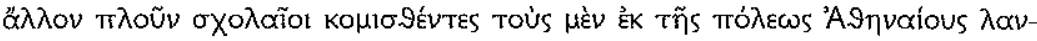

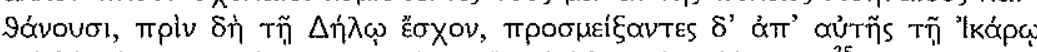

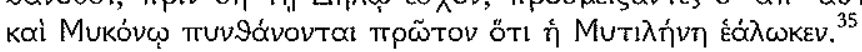

The Peloponnesians in the forty ships, who were supposed to arrive quickly, wasted time even while sailing along the Peloponnesus and were leisurely in making the rest of their voyage, unnoticed by the Athenians in the city as they proceeded until they put in at Delus, and on reaching Icarus and Myconus from there they first learned that Mytilene had been captured.

Together with the focus on the Attic theatre of war, where the Spartans fulfil their promises, the postponement of the information about the 40 Peloponnesian ships makes the capitulation of Mytilene unexpected. The delay of the fleet is imitated by the narrative delay in describing it, $^{36}$ narrative time mimics narrated time and thereby re-creates the presentness of the past.

The two previous references to the ships are focalised by the Peloponnesian (3.26.4). Cf. Rood 1998, 118.

36 Cf $\operatorname{Rood} 1998,118$. 
Our episode features further playing with narrative time worth mentioning, for instance the account of the capture of Notion $(3.34 .3):^{.37}$

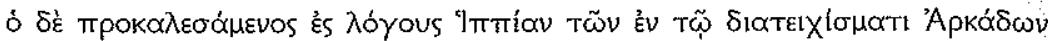

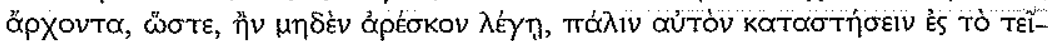

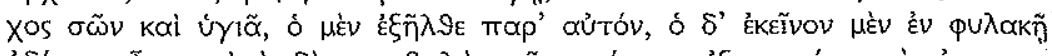

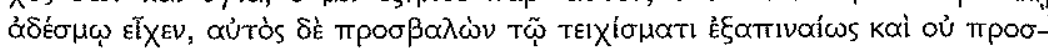

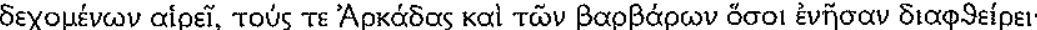

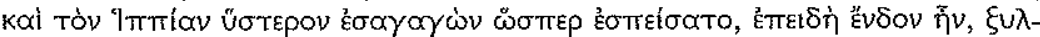

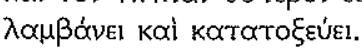

He invited Hippias, the leader of the Arcadians in the fort, to a parley on the understanding that he would let him return safe and sound if he rejected his proposal; he then put him under guard, although not in chains, made a sudden attack on the fort and captured it by surprise, and he killed the Arcadians and all the barbarians inside; Hippias he brought in later, just as he had pledged, and, when he was inside, arrested him and killed him with a bowshot.

In the discussion of the sea battles at Naupactus, I have identified a tendency in Thucydides to lay out the reasoning and plans of historical agents before their actions. Here, on the contrary, Thucydides limits his account to the skeleton of bare facts. His narrative thereby mirrors the suddenness of the action ( $\xi \xi \alpha \pi v \alpha i \omega s)$ and makes it as unexpected for the readers as it was for the partisans in Notion (ou $\pi p \circ \sigma \delta \varepsilon \chi \circ \mu \varepsilon v \omega v$ ). 'Thucydides' narrative technique serves again to convey the experience of the characters, here of the victims of a ruse.

In the episode of Paches' trick, the narrative speed imitates the speed of the action; the following passage, on the other hand, creates a contrast between narrative and narrated time. When Salaithus and the Mytilenean conspirators arrive in Athens, the demos is so enraged that he de-cides to have not only them but all Mytileneans killed (3.36.3):

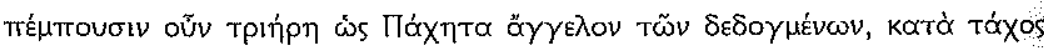
кє $\lambda \varepsilon$ Ư

Accordingly, they sent a trireme to Paches reporting their decision and instructed him to put an end to the Mytileneans without delay.

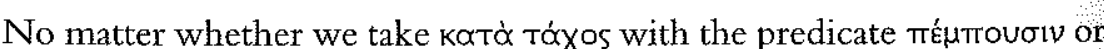

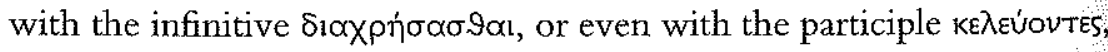

37 On the displacement of the preceding information about the stasis in Notion which took place in $430 \mathrm{BCE}$ and would therefore belong to Book 2, see Hornblower 1994b, 143. the hurry of the Athenians, the speed of the narrated time, contrasts with the deceleration of narrative time effected by the ensuing Mytilenean Debate that extends over 15 chapters. While the preceding account summarizes the events, the reproduction of direct speech in the Mytilenean Debate draws out narrative so that it comes to equal narrated time. This stretching of narrative time throws into relief not only the haste of the first decision, but also the speed necessary to save the Mytilineans in narrated time. Parallel to the discussion of the Athenians, the ship with its lethal mission is on its way to Lesbos: "The longer the debate lasts, the slimmer becomes the chance of salvation for the Mytileneans. There can be no doubt that the historian is conscious of the dranatic element that these speeches... lend to the narrative."38 The Mytilenean Debate thus creates suspense, just as the entire episode can be viewed as a narrative "Beinahe". Nearly all the Mytileneans were killed; only "since by luck there was no opposing wind, and the first ship was

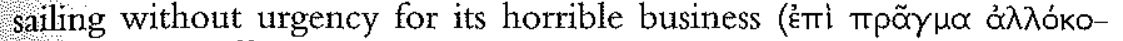
Tov)'" (3.49.4), ${ }^{39}$ the second boat arrived in time to prevent the execution of all Mytilenean men ordered by the first boat: "Mytilene's danger came this close" (3.49.4). "Through the modulation of narrative time, Thucydides re-creates for the readers the suspense that the historical agents must have felt.

\section{"Sideshadowing"}

1 have elsewhere argued that such "Beinahe"-episodes in Thucydides serve as "sideshadowing" devices. "S1 "Sideshadowing" goes against the teleological tendency inherent in retrospective narrative, alerts the reader to other possible historical outcomes and thereby drives home the openness of the past when it was still present. The effect of "sideshadowing" is also prominent in the account preceding the Mytilenean Debate. The brief speech of the Elean Teutiaplus has vexed many scholars. Why, it has been asked, does Thucydides include a speech irrelevant to the action? ${ }^{42}$ After all, Teutiaplus fails to convince Alcidas of his plan

38 Stahl 2003,108 . See also Schwinge $2008,55-6$ on narrative and narrated time in this passage.

39. On the question of who focalises the evaluation $\alpha \lambda \lambda$ óкотоv, see Homblower $1994 b, 135$.

40 Cf. the parallel phrase in 7.2 and Hornblower 1994b, 158; Stahl 2003, 109

41 Cf. Grethlein 2010a, 250-1.

42 Cf. Rawlings 1981, 190, who calls it "the strangest speech in all of Thucydides". It may also be added that such ineffective speeches do not square 
to sail to Mytilene. It is, to use a term coined by Prince, a "disnarrated" element, i.e. a narrative of something that did not take place. ${ }^{43}$ However, the very fact that Teutiaplus' suggestion is not realized establishes its narrative significance, which goes beyond making the readers familiar with the thoughts of historical agents: In pointing "to the road not taken" ${ }^{44}$, the speech serves as a "sideshadowing" device. It calls our attention to another possible course of events. In hindsight, we know that Alcidas will quickly return to the Peloponnese upon learning of the capture of Mytilene, but the speech illustrates the openness of the situation when it still was present - the Peloponnesians could also have sailed to Mytilene and, who knows, have captured it...

This demonstration of the openness of the past is reinforced by the proposition of the Ionian and Mytilenean refugees to sail to Ionia and prompt the defection of the Athenian allies (3.31.1). Although presented only in indirect speech, the "sideshadowing" of this option is developed further than the possibility of a surprise attack on Mytilene. The plan and the potential gain are presented in great detail: the refugees point out that such an enterprise, welcome to the Ionians, would be likely to succeed and would have grave consequences for Athens: it would lose its "greatest source of revenue",45 and would have to shoulder further expenses if it attempted a counterattack. Even the Persian satrap Pissouthnes could be persuaded to join them. The effectiveness of an attack on Ionia is also confirmed by the subsequent narrative. In 3.32.3, Thucydides mentions that Alcidas has caught Chians and others, who, not counting on the possibility of Spartan ships in Ionia, had come to the beach. This incident illustrates the unexpectedness of a Pelopon-

with Hunter's thesis that Thucydides tends to derive purposes from actions. On the effectiveness of speeches in Thucydides in general, see Hornblower 1987, $67-69$, who also discusses the historicity of Teutiaplus' speech (53-4 with n. 31).

43 Prince 1988.

44 Lateiner 1975, 180. See also Stahl 2003, 107, who speaks of a "missed opportunity", but confuses Teutiaplus' and the refugees' suggestion when he claims that the narrative proves his plan right. In 3.32.3 it is Chians who do not expect the appearance of Peloponnesians and the fears in 3.33 .2 are triggered by the lack of fortifications in lonia. Of course, both points could be transferred to Mytilene which, however, was held by Athenian troops. Thus, they seem to support the plan to attack Ionia, on which see below.

45 Kallet-Marx 1993,139-143 argues that this claim does not necessarily contra-

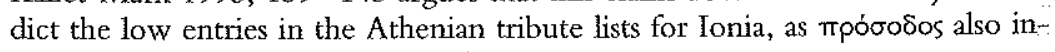
cludes revenues other than this tribute. nesian intervention in Ionia just as the focalisation of the events through Paches underscores its potential to damage the Athenian empire (3.33.2):

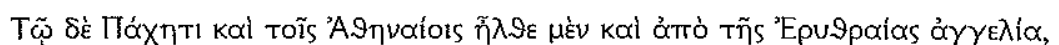

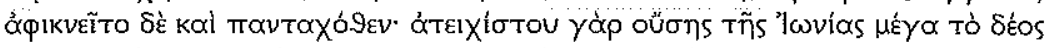

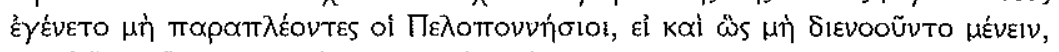

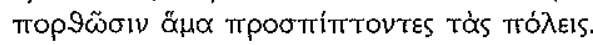

The news reached Paches and the Athenians from Erythrai and then came in from every source: since Ionia was unfortified, there was growing fear that even if the Peloponnesians did not plan to stay, on that account they would fall on the cities and plunder them as they sailed along the coast.

Finally, Paches' relief that he did not catch Alcidas corroborates the calculation of the expenses the Athenians would have incurred, had they

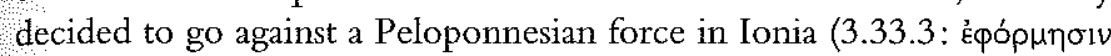

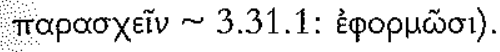

\section{Indirect evaluation}

In my discussion of Phormion's naval successes, I touched upon the indirect evaluation that emerges from the correspondences of speeches with one another and with the narrative. The case of Alcidas furnishes a nice example of indirect evaluation through narrative. As we have seen, the potential of the plan to destabilize Ionia that emerges from Thucydides' account exposes the opportunities missed under the command of Alcidas. A minor episode also shows the Spartan general in a less positive light: Alcidas kills the majority of his Ionian prisoners of war and stops only when an embassy of Chians alerts him that thus "he would convert few enemies to friends but make many more friends into enemies" (3.32.2). Moreover, Alcidas' speedy flight stands in marked contrast to the slowness with which he had come to the aid of Mytilene ${ }^{46}$ His hesitant and fearful mode of operation is also thrown into relief by Paches' capture of Notion. Certainly, the ruse employed by Paches is rather questionable - he promises to send the leader of the Arcadians, Hippias, back "safe and sound" after their negotiations, but then detains him in his camp, attacks and conquers the city and finally

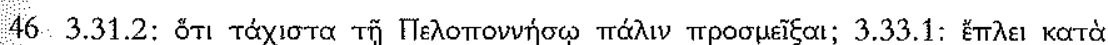

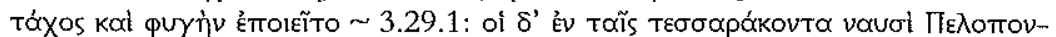

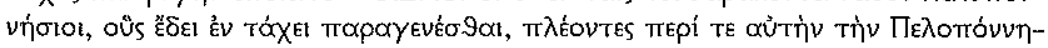

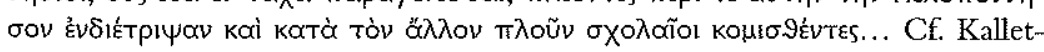
Marx 1993, 139. 
shoots him with an arrow after leading him back into the city - but nonetheless the narrative emphasis on the suddenness of the manoeuvre, as demonstrated above, establishes an effective contrast to Alcidas' slowness. The reflection on speedy actions in Teutiaplus' speech lifts the issue to a general level (3.30.4):

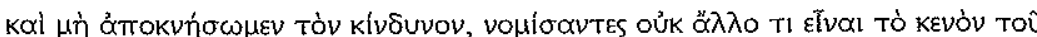

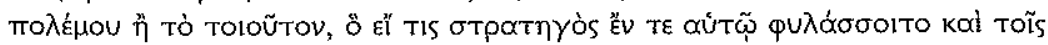
то入

We must not shrink from the danger but understand that, if there is any universal factor in war, it is what I have described; if a general guards against it in his ranks and attacks when he observes it among the enemy, he will have the greatest success.

Again, Thucydides avoids interrupting the course of events with his narratorial voice but nonetheless manages to convey an evaluation by embedding it in his account of the events. As Hornblower on 3.31.2 puts it: "Certainly Th(ucydides) in these [chapters] brilliantly manages to censure Alkidas without open authorial censoriousness" ${ }^{47}$ Such implicit censoriousness is very effective: the evaluation seems to emerge from the events themselves and to be objective just as the narrator's reticence reinforces the experiential quality of the account.

\section{Teleology and Authorial Presence}

Let me briefly summarize and qualify my findings before I add some caveats. Neither the first two sea-battles nor the capture of Mytilene is among the narrative jewels admired for their mimetic quality by ancient and modern critics alike. And yet, both episodes illustrate the means by which Thucydides restores presentness to the past throughout his narrative: time, focalisation, voice, composition and description. The chronological account permits Thucydides to align the reader's

47 For a somewhat exaggerated emphasis on the negative portrayal of Alcidas, see Rawlings 1981, 192, who sees him as a foil for Alcibiades in Book 7 in accordance with his thesis that "Thucydides carefully measured the revolts of Lesbos in 427 and of Chios in 412 against one another, that he contrasted the Athenians' ability to deal with the first revolt with their inability to handle the second, and that he wanted in particular to emphasize the improved effectiveness of the Lacedaemonian response to the second revolt caused by the leadership of Alcibiades". (181). with the characters' experiences. Besides chronological order, the temporal category of speed can contribute to the mimetic power of narrative. Manipulation of the relationship between narrated and narrative time can make an account mimic the events narrated, as, for example, when a rapid-fire report expresses the suddenness of an action. Focalisation helps to put the readers in the shoes of the historical agents and lets them see the events unfold through their eyes. A similar effect is achieved by the large number of speeches in which the historical agents voice their views themselves. Another aspect of voice is the narratorial reticence of Thucydides. As we have seen, evaluations and deeper reflections are often mediated diegetically and therefore seem to derive from the events themselves. Together with the three basic narratological categories of time, focalisation and voice, composition can increase the experiential appeal of an account, for example through the "sideshadowing" of "Beinahe"-episodes which alerts the reader to the possibility of alternative developments. Thucydides also uses the non-narrative form of description ${ }^{48}$ to make his account graphic, a technique discussed as enargeia already by ancient critics.

From time to time, Thucydides interrupts the flow of the narrative to reflect. A prominent example of this is the appraisal of Pericles whose brilliance is thrown into relief through a comparison with his successors $(2.65 .10-13)$.

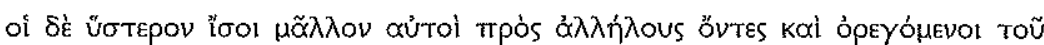

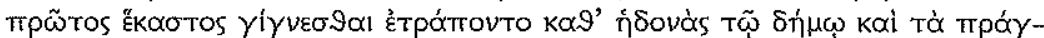

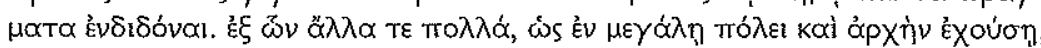

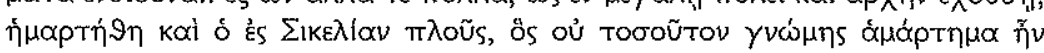

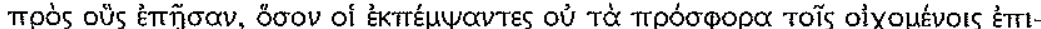

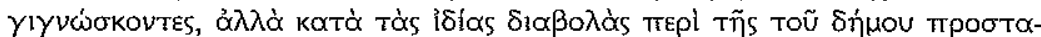

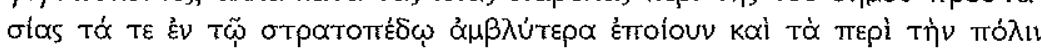

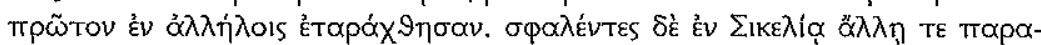

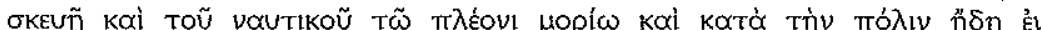

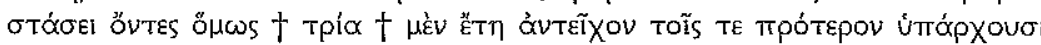

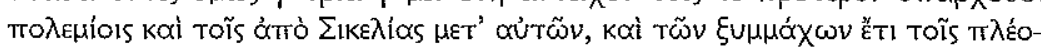

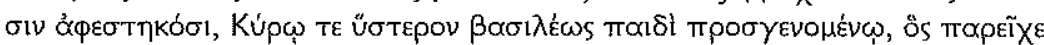

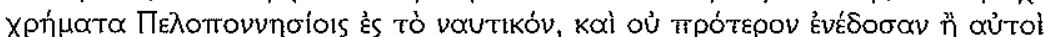

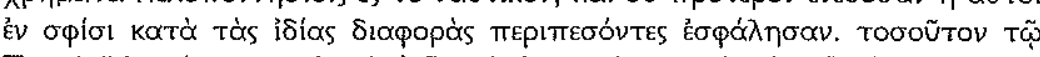

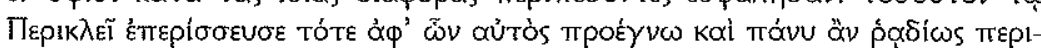

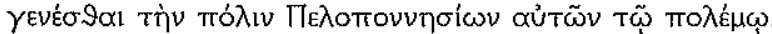

48 On description as an alternative medium of representation to narrative, see Wolf/Bernhardt 2007 
Those who came later, by contrast, since they were more on an equal level with one another and each was striving to become first, even resorted to handing over affairs to the people's pleasure. As a result, many mistakes were made, since a great city ruling an empire was involved, especially the expedition to Sicily, which was a mistake not so much of judgment about those they were attacking as because the senders did not subscquently. make decisions advantageous for the participants, but by engaging in personal attacks over the leading position among the common people they both reduced the vigour of the armed forces and for the first time fell into confusion in the administration of the city. And after they had failed in Sicily, not only with their other forces but also with the larger part of the fleet, and now had a revolutionary situation in the city, they nevertheless still held out for three years against both their previous enemies and those from Sicily along with them, and moreover the majority of their al lies, who had revolted, and later against Cyrus the king's son in addition, who furnished the Peloponnesians with money for their fleet, and they did not give in until, coming to grief through individual disputes, they brought about their own overthrow. So great at the time was the abun dance of resources at Pericles' disposal, through which he foresaw that the city would very easily prevail in the war over the Peloponnesians alone:

The evaluation of Pericles not only flashes the presence of the narrator, it also embeds in the account of the beginning of the Peloponnesian War a foreshadowing of its end. Thucydides is very reticent with prolepses" and, claiming that he "began his work as soon as the war

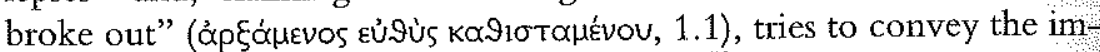
pression that he wrote parallel to the events. ${ }^{50}$ And yet, the praise for Pericles unveils the teleological design of The History of the Peloponnesian War. The text, as we have it, breaks off mid-sentence in $411 \mathrm{BCE}$, but the second prologue in 5.26 leaves no doubt that the capitulation of Athens in 404/3 BCE forms the telos of the narrative. Thucydides narrates the conflict between Athens and Sparta from the vantage-point of the former's capitulation. Since modern historians have more or less adopted this view of the Peloponnesian War, this may seem natural to us, but ancient testimonies illustrate other possible takes: Fourth-cen tury orators distinguish between several wars (Andoc. 3.3-9;29-31, Aeschin. 2.173-6) and Dionysius of Halicarnassus suggests envisaging the Peloponnesian War from the vantage-point of the return of the exiles (Pomp. 3.10). Thucydides' choice of 404/3 BCE as telos has an in pact on his account: His critique of Athenian orators, for instance, de

49 For further prolepses in Thucydides, see Dunn 2007, 116.

50 Homblower 1991, ad loc. nicely elicits the tension in Thucydides' claim: “Th sat down to record a set of events which were still in the future". rives its fierceness from being causally linked to Athens' defeat. Even an author who foregrounds experience to such a degree as Thucydides cannot evade the spell of hindsight.

That being said, the teleological design of Thucydides' narrative is well-hidden. The two episodes I have discussed, for example, do not contain prolepses that alert the reader to the impact of retrospect. They do feature, however, examples of authorial intrusion that go against narrative mimesis. Thucydides' authorial reticence is remarkable, but from time to time he flashes his presence. ${ }^{51}$ Let me give one obvious and one less obvious example: After narrating Salaithus' arrival in Mytilene, Thucydides writes (3.25.2):

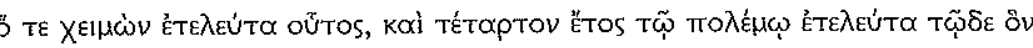

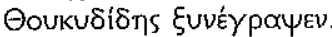

And the winter ended, also the fourth year of the war which Thucydides recorded.

Here and in other passages, reference to the author pointedly highlights his presence in the narrative. While the general reticence enhances the mimetic appeal of the narrative, such intrusions assert Thucydides' authority over his text. ${ }^{52}$ The mediating presence of the author is marked more subtly, but is nonetheless visible in 2.86.5:

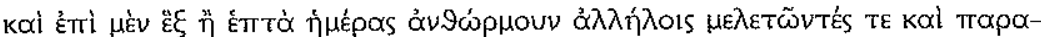

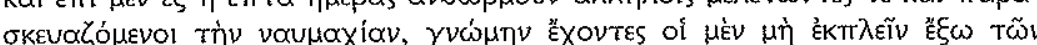

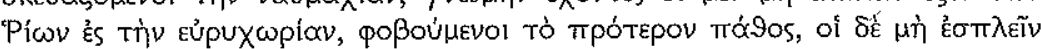

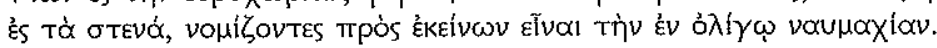

And for six or seven days they remained at anchor across from each other, practicing and preparing for a sea battle, one side resolved not to sail outside the two Rhions into open water, for fear of the earlier disaster; the other side, not to sail into the narrows, thinking that in a limited space the battle would be in the enemy's favor.

The "or" (ท) reveals the author's uncertainty about a minor fact - the exact number of days the fleets faced each other - but this alerts the reader to the fact that we access the past only through the author's reconstruction. ${ }^{53}$ Passages like this unveil the presence of a narrator who,

51 This is emphasized by Rood 2006

52. Cf. Gribble 1998, 43

53 Cf. Hornblower 1994b, 151, who emphasizes that such hedges are very rare in Thucydides. 
however, has crafted a narrative that by and large seems to follow the events themselves.

\section{The presence of the past in Thucydides and Plutarch}

In de gloria Atheniensium, Plutarch praises the enargeia of Thucydides' narrative, highlighting the visual quality and emotional grip that give the reader the sense of witnessing the events while they are unfolding. Plutarch himself receives good press for the enargeia of his Lives. Russell, for example, hails him as "one of the most evocative reconstructors of the past" and even claims: "Few writers (perhaps only Livy among the ancients, and in a much more limited way) display such zest as Plutarch for the colourfulness of history and the excitement of action and adventure" ${ }^{54}$ The parallel praise makes it tempting to compare the vividness in both authors. This comparison can only be sketched in broad outline here, but it will help throw into relief the experiential quality of Thucydides' narrative.

To start with some obvious points: in the Lives speeches are less frequent and tend to be much shorter than in the History of the Peloponiesian War. Volumnia's supplication of her son in the Coriolanus is as long as it gets. Focalisation is certainly an arrow in Plutarch's narratorial quiver, but he uses it less extensively than Thucydides. Likewise, counterfactuals and "Beinahe-episodes" are less prominent. Plutarch's voice is strongly present not only in the proems and the concluding synkriseis, but throughout the narrative which is punctuated by frequent narratorial intrusions. At the same time, it is not difficult to find in the Lives the graphic quality that Plutarch extols in Thucydides. Take for example the taming of Bucephalus in the Alexander (6), which not only illustrates the enargeia of the Lives, but also lets us grasp a crucial difference between Plutarch and Thucydides: ${ }^{55}$ After sketching the background, namely Philip's annoyance at the failure of all attempts to break the immensely expensive horse, Plutarch reports a brief dialogue between son and father, in which Alexander bets the price of the horse that he will be able to tame him (6.1-4). He succeeds (6.5-7) and impresses the spectators including his father who, Plutarch says at the end, is reported to

54 Russell 1995, 76, 81

55 On the scene, see Frazier 1992, 4496-9; Stadter 1996, 291-6. For the various traditions on Bucephalus, see Anderson 1930. have said: "My son, seek thee out a kingdom equal to thyself; Macedo-

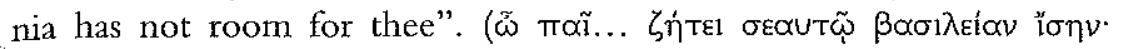

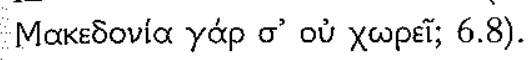

The scenery itself is very vague, ${ }^{56}$ but nonetheless "the story is vividly told, as if by an eyewitness, and sticks in the imagination". ${ }^{57}$ In addition to the direct speech in which the dialogue between father and son is rendered, the detailed description of the taming endows the scene with enargeia. Plutarch uses a long string of compound verbs, some of them rare, whose prefixes create a strong spatial deixis: Alexander

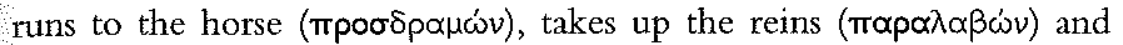
turns the horse towards the sun $(\varepsilon \dot{\varepsilon} \dot{\varepsilon} \sigma \tau \rho \varepsilon \psi \varepsilon)$, since he has noticed that Bucephalus is disturbed by his shadow falling in front of him (okıờv тротіптойav, 6.5). Alexander then trots besides Bucephalus

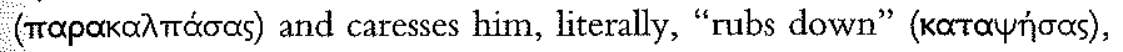
before he throws away his mantle (åmoppiuas) and mounts the horse, literally, "encircles" him ( $\pi \epsilon \rho l \varepsilon \beta \eta, 6.6)$. Drawing the reins both on the left and the right side $(\pi \in p \imath \lambda \propto \beta \omega \omega)^{58}$, Alexander holds in Bucephalus ( $\pi \rho \circ \sigma \alpha v \varepsilon \dot{\sigma} \sigma \varepsilon ı \lambda \varepsilon v, 6.7$ ). The detailed spatial deixis, meticulously charting every movement of Alexander, makes the scene highly graphic - while reading Plutarch's description, it is hard not to see Alexander and Bucephalus before one's inner eye.

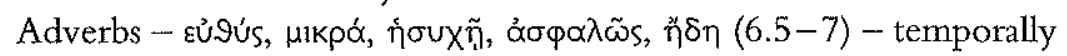
nuance the single steps just as the sequence, told in the aorist, receives temporal depth from imperfect forms and present and perfect participles: Alexander "saw ( $(\dot{\omega} \rho \alpha)$ that he [i.e. Bucephalus] was filled ( $\pi \lambda \eta-$

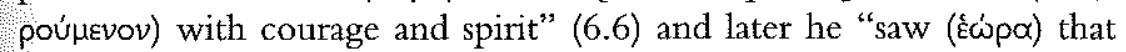

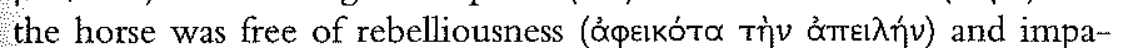

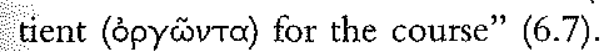

While Alexander carefully watches Bucephalus, he is observed by Philip and the others of whom some at least have failed to tame the horse. The spectators form an internal audience that brings the reader close to the scene. They first laugh about the bet (6.5), are then silent and finally break out in war-cries (6.8). Plutarch does not interrupt the account of the taming and reports their silence only subsequently. ${ }^{59}$

56 Cf. Frazier 1992, 4497

57 Stadter 1996, 292.

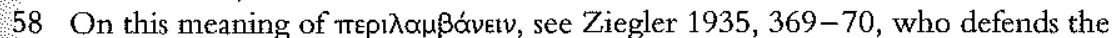
transmitted form against the various conjecture.

59 Cf. Frazier 1992, 4499. 
This is not only a highly appropriate way of rendering the silence that contributes nothing to the taming, but also makes the reactions of the spectators frame the scene just as they surrounded the place where Alexander mounts Bucephalus. The temporal ordering thus mirrors the spatial lay-out of the scene.

The breaking of Bucephalus is placed prominently at the beginning of the biography and interpreters have been quick to ascribe to it deeper significance than merely reporting an incident from Alexander's youth. The anecdote establishes major features of Alexander's character, notably his wit, ambition and brashness. ${ }^{60}$ Furthermore, Philip's dictum with which Plutarch closes the scene directly alerts the reader to Alexander's later conquests: Alexander will subjugate entire countries just as he tamed Bucephalus. ${ }^{61}$ Two minor points may buttress this interpretation that aligns the taming with the later military conquest: Alexander leads Bucephalus toward the sun which is associated with the East where he will make his conquests. Moreover, in Philip's dictum it is natural to refer

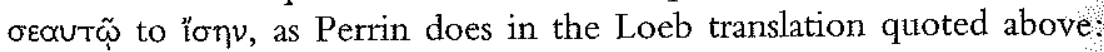
Alexander ought to seek a kingdom equal to himself. At the same time, the sentence can be construed differently if we correlate oøautw

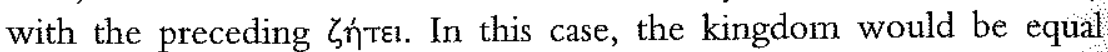
to the horse and the prefiguration of the conquests in the taming explicit. $^{62}$

The anecdote of the taming of Bucephalus is highly graphic, but at the same time does not generate narrative suspense. We are not left wondering what will happen next; instead, Plutarch sketches a picture of Alexander that goes beyond his comportment in a particular situation. In taking an incident out of the flux of time and making it metaphorically encapsulate later events, the vignette freezes the sequence of time and spatializes history: important traits of Alexander are revealed in the close-up of a scene. This is emblematic of Plutarch's tendency to break the flux of time into episodes the significance of which goes beyond the moment. Vagueness of time, downplaying of temporal links and explicit thematic ordering give the Lives, despite their chronological

60 Cf. Stadter 1996, 292

61 C. Beck 2007, 398.

62 Another interpretation takes Bucephalus as the "equine counterpart of Alexander": Anderson 1930; Stadter 1996, 293-4. frame, an episodic character. ${ }^{63}$ This is not a failure on the part of Plutarch, but reflects his focus on character and morals. Instead of trying to evoke the temporal horizon of the past, Plutarch aspires to the level of moral values that in his eyes is timeless. For him, detailed description is not a means of restoring presentness to the past, but to make anecdotes memorable and thereby drive home moral points.

Plutarch's vividness throws into relief the experiential quality of Thucydides' writing. There are also vignettes in the History of the Peloponnesian War, but its mimesis rests rather on a sequential account that makes the reader follow the action from the perspective of the characters. While Plutarch tends to string together closed episodes, Thucydides is at pains to restore the temporal horizon of the past. He thereby strives to align the reading experience with the experience of the historical agents, enabling the readers to re-experience the past as if it were still present. The difference can be grasped in Plutarch's own words. In the prologue to the Aemilius and Tinoleon, he elaborates on the didactic function of his Lives that extends to himself $(1.2-3)$, " ... trying in the mirror of history to adorn life somehow and adjust it to the virtues of those men. For the result is like nothing other than daily living and associating together, when I receive and welcome each subject of my history in turn as my guest...": Thucydides, as Plutarch perceptively puts it, makes us witnesses of past events. $\mathrm{He}$, on the other hand, makes the heroes of the past visit us. Thucydides and Plutarch both strive for a close encounter with the past, but in different directions: While in Thucydides an experiental narrative enmeshes us in the past, Plutarchan enargeia brings past virtues to us.

This illustrates that the experiential quality on which I have elaborated is differently nuanced from the enargeia discussed by ancient critics. ${ }^{64}$ The most salient aspect of enargeia is the visual quality of narrative that transforms the listener or reader into a spectator. ${ }^{65}$ The Anonymus Seguerianus, for instance, defines enargeia as ' $\lambda$ ' $\gamma o s$ úm' ö $\psi l v$ ơ $\gamma \omega \omega$ Tò

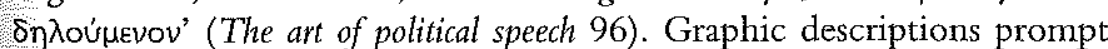

63 The prominence of non-chronological ordering in the Lives has been emphasized by Weizsäcker 1931. See also Russell 1973, 102-3; 115-16; Stadter 1989, xxxy-vii.

64 On ancient discussions of enargeia, see Zanker 1981; Manieri 1998; Otto 2009; Webb 2009.

65 Cf Zanker 1981, 309-10. Manieri 1998, 106, 123 with n. 404. On the other hand, Demetrius, On style 216 and Quintilian Inst. 9.2.41 illustrate that the aspect of time is not entirely absent from ancient discussions of enargeia. 
the reader to visualize a scene and can thereby enhance the mimesis of a narrative. At the same time, the longer descriptions are, the more they interrupt the sequence of the narrative which is crucial to the reader's re-experiencing the past. There is thus some tension between the temporal aspect of narrative's expericntial quality and the visual appeal foregrounded in the concept of enargeia. While The History of the Peloponne sian War features only a limited number of graphic vignettes, the two episodes discussed in this article illustrate the experiential quality throughout its narrative.

\section{The Cylon Conspiracy:} Thucydides and the Uses of the Past

\section{TIM ROOD}

Modern historians of Athens are at once confronted by the gloomy fact that "the first clearly attested event in Athenian history" is Cylon's attempt to become tyrant of Athens in (perhaps) 636 or $632 \mathrm{BCE}$ and yet "the detail, already controversial before Herodotus' birth, is by now irrecoverable". Among ancient literary critics, however, Cylon did achieve a certain fame for the way his attempted coup was presented in the histories of Herodotus and Thucydides. Thucydides' account, in particular, was renowned as the place where (in a scholiast's phrase) "the lion laughed". ${ }^{2}$ Modern scholars have preferred to apply the term "Herodotean" to Thucydides' Cylon narrative together with the accounts of Pausanias and Themistocles that follow it. ${ }^{3}$ Yet easy recourse to the term "Herodotean" has the paradoxical effect of "buttressing the opposition"4 between Herodotus and Thucydides - as if labelling an apparently abnormal section "Herodotean" is enough to excuse the abnormality and stop further questioning. The danger of this approach is especially apparent when Thucydides' "Herodotean" manner is held to show that a section was written "early" or even for a different context altogether. ${ }^{5}$ The aim of this paper is to try to understand not just

Andrewes 1982, 368-9, 370; cf. Thomas 1989, 288; Osborne 1996, 215-16.

2. Scholiast ad loc, repeated by Romanus Sophista 3 (p. 2. 11. 17-18 Camphausen) and by John Sikeliotes $6.504 \mathrm{Walz}$, who also noted the account's "gracefulness", explaining that it was "very clear" and not at all like the historian's usual "gravity"; Patterson 1993 extends the saying to the Cylon, Pausanias, and Themistocles retrospects $(1.126-38)$ as a whole. Aelius Theon, a rhetorician of the firs century CE, in a pedagogic text (Prog. ii. 66 Spengel), ranked both Herodotus' and Thucydides' tales of Cylon as among "the finest examples of narrative" E.g. Pothou 2009, 122

4. H.g. Pothou 2009

5. Early: Westlake 1969b. Different context: Canfora 1982, arguing that Thucydides first planned to write a sequel to Herodotus which would have included digressions on the past, and that 1.126-38 is a remnant of this original plan adapted to a new role. My attempt to explain unusual elements of the Cylon 